\title{
Maxillofacial Trauma and Alcohol Abuse: A Descriptive Cross Sectional Study
}

\author{
S. Devakumari ${ }^{1}$, T. Vijhayapriya ${ }^{2}$, Nandini Biradar ${ }^{3}$, P. Amudha ${ }^{4}$, D.S. Dinesh ${ }^{5}$, S. Devameena ${ }^{6}$ \\ ${ }^{1}$ Oral and Maxillofacial Surgeon, Associate Professor and HOD, Department of Dentistry, Indira Gandhi \\ Medical College \& Research Institute (Govt.), Puducherry-605008, India, ${ }^{2}$ Associate Professor, Department \\ of Ophthalmology, Indira Gandhi Medical College \& Research Institute (Govt.), Puducherry-605008, India, \\ ${ }^{3}$ Associate Professor, Department of Dentistry, Bidar Institute of Medical Sciences, Bidar, Karnataka-585401, \\ India, ${ }^{4}$ Assistant Professor, Department of Ophthalmology, Indira Gandhi Medical College \& Research Institute \\ (Govt.), Puducherry-605008, India, ${ }^{5}$ Professor and HOD, Department of Conservative Dentistry and Endodontics, \\ Sri Venkateswara Dental college and Hospital, ARIYUR, Puducherry-605008, India, ${ }^{6}$ Senior Lecturer, \\ Department of Prosthodontics and Crown and Bridge, Sri Venkateswara Dental College and Hospital, ARIYUR, \\ Puducherry-605008, India
}

\begin{abstract}
Background: To assess the relationship of alcohol abuse in maxillofacial trauma in a tertiary care hospital, Puducherry, South India.

Materials and Method: A descriptive cross sectional study was done by retrieving the patient's inpatient and operative records from the year 2011 to 2018. The parameters that were assessed includes association of the alcohol during injury, etiology, demographic data and the type of fracture.

Conclusion: The descriptive analysis of the facial fractures in Puducherry, INDIA provides an insight in to type of facial fractures and their etiology recorded in patients with alcohol abuse during injury. These kinds of studies in the particular geographical region are important in developing prevention strategies.
\end{abstract}

Keywords: Alcohol abuse, maxillofacial, fracture, mandible, zygoma.

\section{Introduction}

Alcohol consumption is an increasing social trend nowadays in any part of India. Over indulgence of alcohol and injuries under the influence of alcohol is commonly encountered in maxillofacial trauma management settings. Face is the most targeted part of the body for all interpersonal violence throughout the world. Interpersonal violence and alcohol consumption has an inseparable correlation. Roads should have made safer for all citizens because a large percentage of

\section{Corresponding Author:}

Dr. P. Amudha MBBS. DNB

Assistant Professor, Department of Ophthalmology, Indira Gandhi Medical College \& Research Institute (Govt.), Puducherry-605008, India population-children, pedestrians, cyclists, motorcyclists, and the elderly are most vulnerable ${ }^{1}$. Indian researches on road safety measures claim that alcohol consumption is a threat to our civilization leading to premature life loss and downstream ones economic status. This must be prevented by a holistic approach on this firing issue ${ }^{2}$. According to WHO, RTA accounts for 9 th position of DALY (disability-adjusted life year) loss but in 2020 it can reach to third position ${ }^{3,4,5}$. With the present scenario of alcohol consumption due to increase social activities in young adults, we conducted a descriptive cross sectional study on the influence of alcohol and the correlation with maxillofacial trauma patterns in Puducherry, south India.

\section{Materials and Method}

The descriptive study was carried out for the period of 7 years (2011-2018) at the Department of Dentistry, 
IGMC \& RI after getting ethical committee clearance (IEC no: 17/163/IEC/PP/2018).In patient records were retrieved and data were entered in a structured proforma. Data retrieved were analysed using SPSS SOFTWARE - 24. The compiled data were analysed using descriptive and inferential statistics. The parameters that were assessed include association of the alcohol during injury, etiology, demographic data and the type of fracture.

Inclusion Criteria: Maxillofacial trauma victims of both the genders in the age group of 18 to 65 years were included in the study.

Maxillofacial fractures that had occurred when patient was under the influence of alcohol (H/O alcohol consumption within six hours before the trauma)

Patients with isolated maxillofacial fractures

Patients who underwent surgery for maxillofacial fractures

RTA involving -motorised/non motorised two wheelers (both as riders and pillion riders),

- $\quad$ Light motor vehicles/heavy motor vehicles

- $\quad$ and pedestrians vs. any motorised vehicle

Self fall under the influence of alcohol

Interpersonal assault

\section{Exclusion Criteria:}

Pregnant females

Unconscious patients

Poly trauma

Pan facial fractures

Maxillofacial fractures treated by conservative method

Soft tissue injuries without fractures

\section{Isolated Dentoalveolar fractures}

The study population of $100(\mathrm{~N}=100)$ samples fulfilled the above criteria and were included in the study.

\section{Results}

Out of 163 patients operated for 7 years (2011-2018) in the Department of Dentistry,100 patients suffered maxillofacial fracture under the influence of alcohol $(\mathrm{N}=100)$.

\section{Table 1: Frequencies and proportions of parameters} assessed.

\begin{tabular}{|c|c|c|c|}
\hline Parameters & Group & Frequency & Percent \\
\hline \multirow{6}{*}{ Age } & 20 and below & 9 & 9.0 \\
\hline & $21-30$ & 33 & 33.0 \\
\hline & $31-40$ & 24 & 24.0 \\
\hline & $41-50$ & 24 & 24.0 \\
\hline & $51-60$ & 8 & 8.0 \\
\hline & $>60$ & 2 & 2.0 \\
\hline \multirow{2}{*}{ Gender } & Male & 94 & 94.0 \\
\hline & Female & 6 & 6.0 \\
\hline \multirow{3}{*}{ Etiology } & Assault & 14 & 14.0 \\
\hline & RTA & 60 & 60.0 \\
\hline & Self fall & 26 & 26.0 \\
\hline \multirow{10}{*}{$\begin{array}{l}\text { Type of } \\
\text { Fracture }\end{array}$} & Angle Mandible & 22 & 22.0 \\
\hline & Body Mandible & 12 & 12.0 \\
\hline & Condyle Mandible & 14 & 14.0 \\
\hline & $\begin{array}{l}\text { Parasymphysis } \\
\text { Mandible }\end{array}$ & 8 & 8.0 \\
\hline & Symphysis Mandible & 4 & 4.0 \\
\hline & Lefort I Maxilla & 1 & 1.0 \\
\hline & Lefort II Maxilla & 2 & 2.0 \\
\hline & Lefort III Maxilla & 1 & 1.0 \\
\hline & Zygoma & 10 & 10.0 \\
\hline & Zygomatic Arch & 26 & 26.0 \\
\hline
\end{tabular}




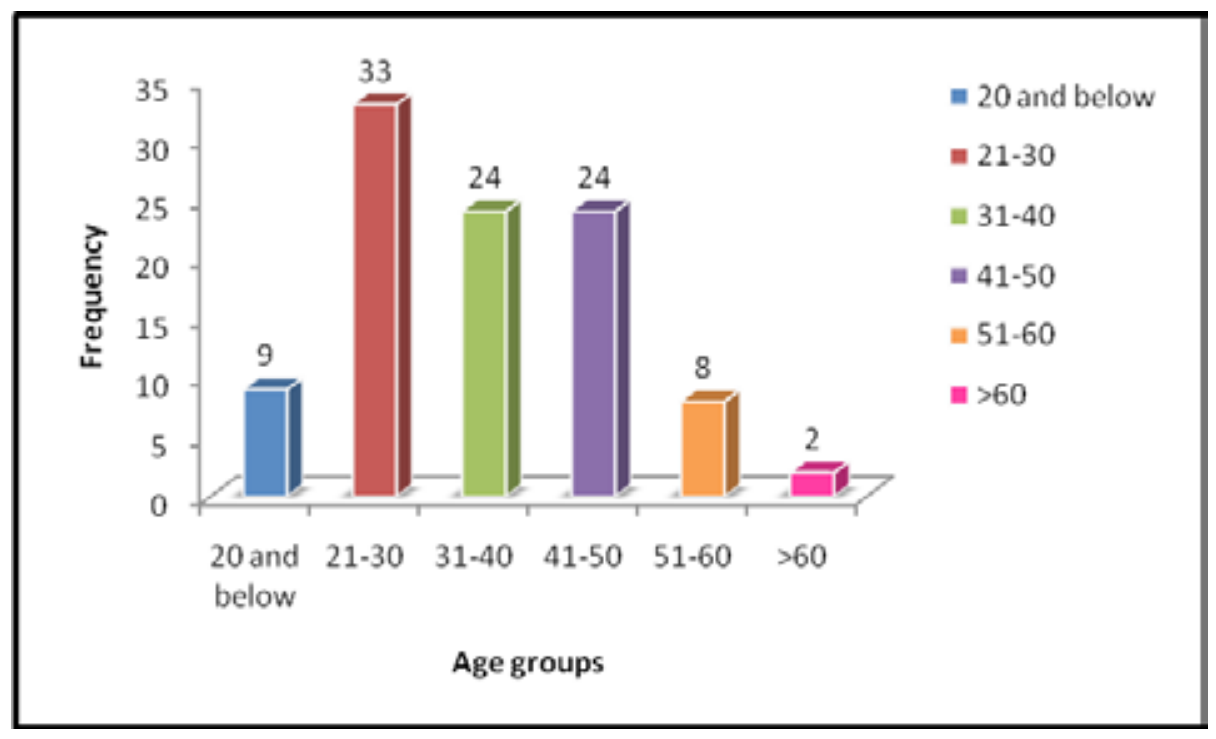

Fig:1 Frequency -age group.

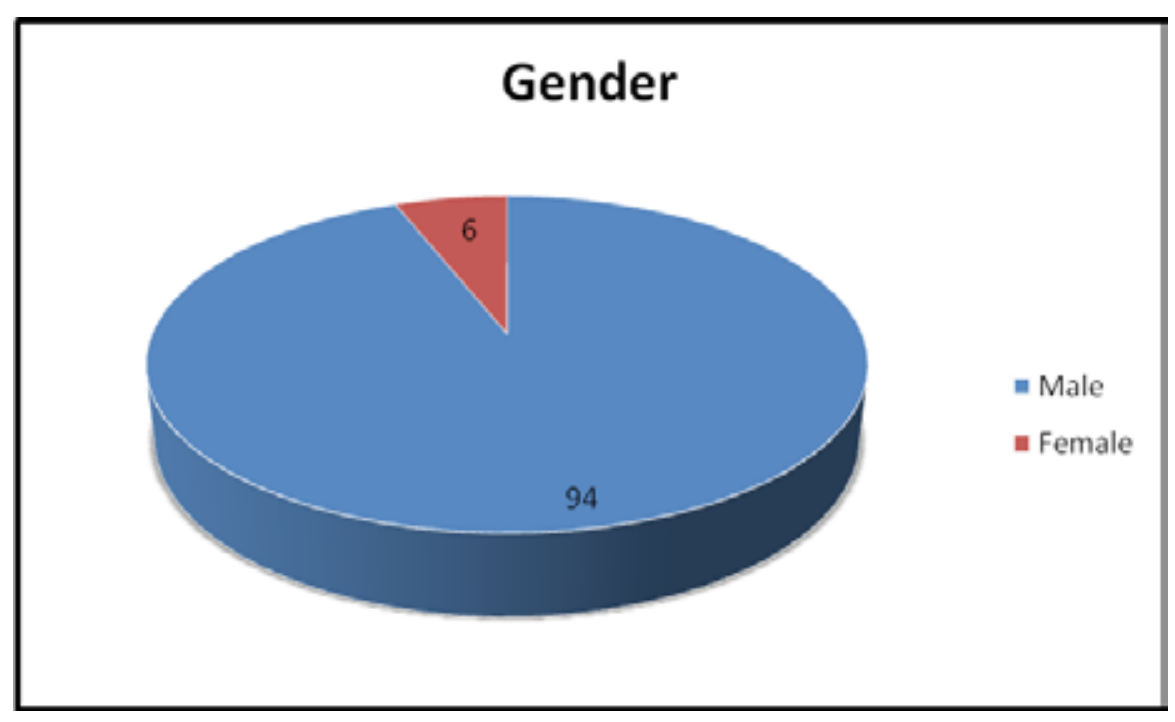

Fig:2 Gender distribution

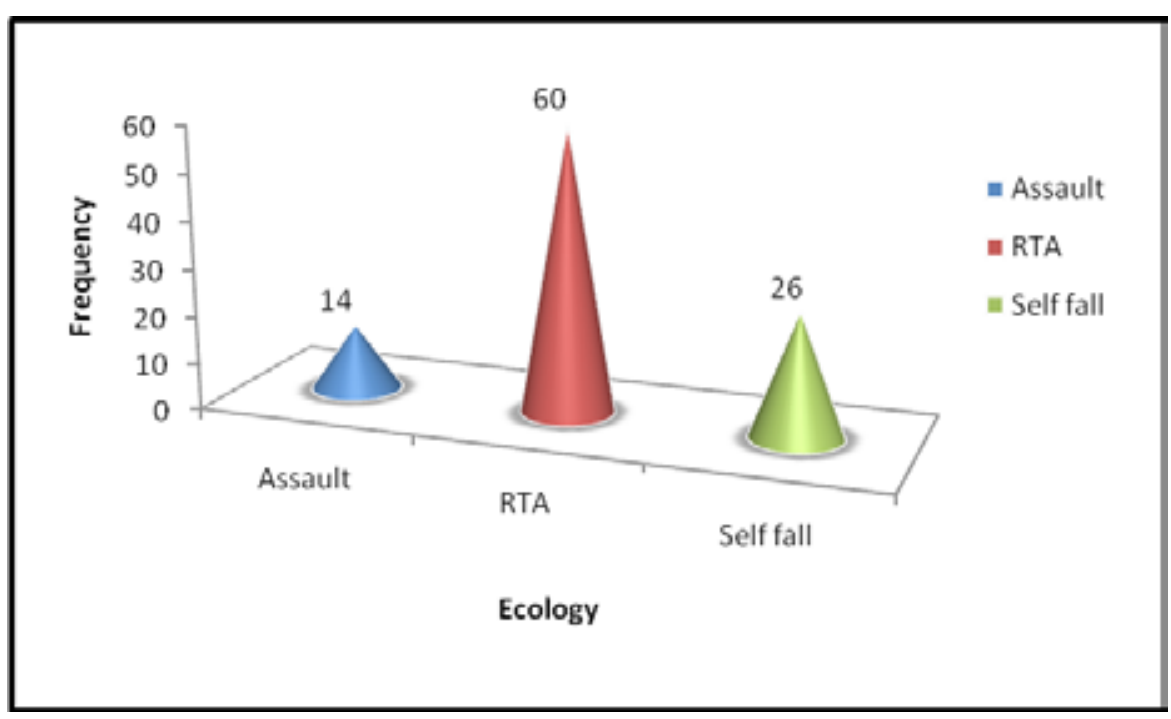

Fig :3 Frequency-Etiology 


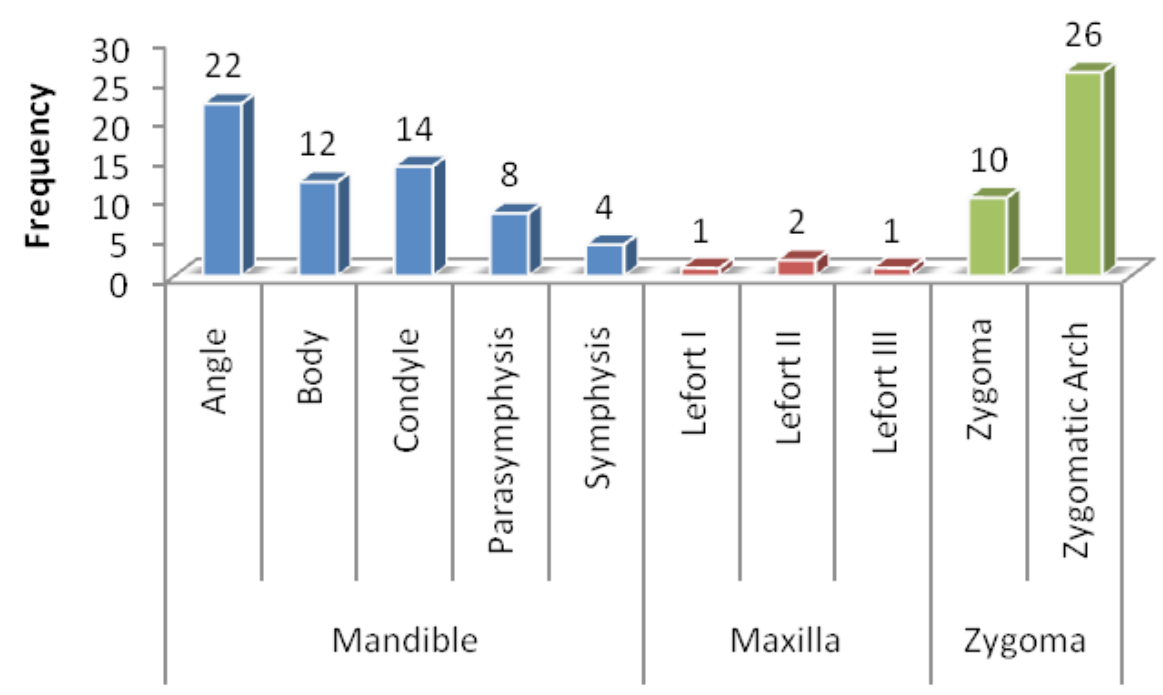

Type of fracture

Fig :4 Frequency- type of fracture

Table 2: Association between etiology and the age group

\begin{tabular}{|c|c|c|c|c|c|c|c|c|c|c|c|c|c|c|c|c|}
\hline \multirow{3}{*}{ Etiology } & \multicolumn{12}{|c|}{ Age Group } & \multirow{2}{*}{\multicolumn{2}{|c|}{ Total }} & \multirow{3}{*}{$\begin{array}{c}\text { Chi } \\
\text { Square }\end{array}$} & \multirow{3}{*}{ P Value } \\
\hline & \multicolumn{2}{|c|}{$\leq \mathbf{2 0}$} & \multicolumn{2}{|c|}{$21-30$} & \multicolumn{2}{|c|}{$31-40$} & \multicolumn{2}{|c|}{$41-50$} & \multicolumn{2}{|c|}{$51-60$} & \multicolumn{2}{|c|}{$>60$} & & & & \\
\hline & $\mathbf{N}$ & $\%$ & $\mathbf{N}$ & $\%$ & $\mathbf{N}$ & $\%$ & $\mathbf{N}$ & $\%$ & $\mathbf{N}$ & $\%$ & $\mathbf{N}$ & $\%$ & $\mathbf{N}$ & $\%$ & & \\
\hline Assault & 4 & 44.4 & 3 & 9.1 & 2 & 8.3 & 5 & 20.8 & 0 & 0.0 & 0 & 0.0 & 14 & 14.0 & & \\
\hline RTA & 4 & 44.4 & 19 & 57.6 & 16 & 66.7 & 14 & 58.3 & 5 & 62.5 & 2 & 100.0 & 60 & 60.0 & 13.036 & 0.222 \\
\hline Self fall & 1 & 11.1 & 11 & 33.3 & 6 & 25.0 & 5 & 20.8 & 3 & 37.5 & 0 & 0.0 & 26 & 26.0 & & \\
\hline
\end{tabular}

Table 3: Distribution of fracture in different age groups

\begin{tabular}{|c|c|c|c|c|c|c|c|c|c|c|c|c|c|c|c|c|}
\hline \multirow{3}{*}{ Etiology } & \multicolumn{12}{|c|}{ Age Group } & \multirow{2}{*}{\multicolumn{2}{|c|}{ Total }} & \multirow{3}{*}{$\begin{array}{c}\text { Chi } \\
\text { Square }\end{array}$} & \multirow{3}{*}{$\begin{array}{c}\mathbf{P} \\
\text { Value }\end{array}$} \\
\hline & \multicolumn{2}{|c|}{$\leq \mathbf{2 0}$} & \multicolumn{2}{|c|}{ 21-30 } & \multicolumn{2}{|c|}{$31-40$} & \multicolumn{2}{|c|}{$41-50$} & \multicolumn{2}{|c|}{$51-60$} & \multicolumn{2}{|c|}{$>60$} & & & & \\
\hline & $\mathbf{N}$ & $\%$ & $\mathbf{N}$ & $\%$ & $\mathbf{N}$ & $\%$ & $\mathbf{N}$ & $\%$ & $\mathbf{N}$ & $\%$ & $\mathbf{N}$ & $\%$ & $\mathbf{N}$ & $\%$ & & \\
\hline Angle Mandible & 3 & 33.3 & 8 & 24.2 & 5 & 20.8 & 5 & 20.8 & 1 & 12.5 & 0 & 0.0 & 22 & 22.0 & & \\
\hline Body Mandible & 1 & 11.1 & 4 & 12.1 & 4 & 16.7 & 2 & 8.3 & 1 & 12.5 & 0 & 0.0 & 12 & 12.0 & & \\
\hline Condyle Mandible & 3 & 33.3 & 4 & 12.1 & 2 & 8.3 & 4 & 16.7 & 1 & 12.5 & 0 & 0.0 & 14 & 14.0 & & \\
\hline $\begin{array}{l}\text { Para symphysis } \\
\text { Mandible }\end{array}$ & 0 & 0.0 & 6 & 18.2 & 1 & 4.2 & 0 & 0.0 & 0 & 0.0 & 1 & 50.0 & 8 & 8.0 & & \\
\hline $\begin{array}{l}\text { Symphysis } \\
\text { Mandible }\end{array}$ & 0 & 0.0 & 0 & 0.0 & 0 & 0.0 & 3 & 12.5 & 0 & 0.0 & 1 & 50.0 & 4 & 4.0 & 66.707 & 0.019 \\
\hline Lefort I Maxilla & 1 & 11.1 & 0 & 0.0 & 0 & 0.0 & 0 & 0.0 & 0 & 0.0 & 0 & 0.0 & 1 & 1.0 & & \\
\hline Lefort II Maxilla & 0 & 0.0 & 0 & 0.0 & 0 & 0.0 & 1 & 4.2 & 1 & 12.5 & 0 & 0.0 & 2 & 2.0 & & \\
\hline Lefort III Maxilla & 0 & 0.0 & 1 & 3.0 & 0 & 0.0 & 0 & 0.0 & 0 & 0.0 & 0 & 0.0 & 1 & 1.0 & & \\
\hline Zygoma & 1 & 11.1 & 2 & 6.1 & 2 & 8.3 & 5 & 20.8 & 0 & 0.0 & 0 & 0.0 & 10 & 10.0 & & \\
\hline Zygomatic arch & 0 & 0.0 & 8 & 24.2 & 10 & 41.7 & 4 & 16.7 & 4 & 50.0 & 0 & 0.0 & 26 & 26.0 & & \\
\hline
\end{tabular}


Table 4: Association between type of fracture and etiology

\begin{tabular}{|c|c|c|c|c|c|c|c|c|c|c|}
\hline \multirow{3}{*}{ Type of fracture } & \multicolumn{6}{|c|}{ Etiology } & \multirow{2}{*}{\multicolumn{2}{|c|}{ Total }} & \multirow{3}{*}{$\begin{array}{c}\text { Chi } \\
\text { Square }\end{array}$} & \multirow{3}{*}{$\begin{array}{c}\mathbf{P} \\
\text { Value }\end{array}$} \\
\hline & \multicolumn{2}{|c|}{ Assault } & \multicolumn{2}{|c|}{ RTA } & \multicolumn{2}{|c|}{ Self fall } & & & & \\
\hline & $\mathbf{N}$ & $\%$ & $\mathbf{N}$ & $\%$ & $\mathbf{N}$ & $\%$ & $\mathbf{N}$ & $\%$ & & \\
\hline Angle Mandible & 8 & 57.1 & 11 & 18.3 & 3 & 11.5 & 22 & 22.0 & \multirow{10}{*}{29.877} & \multirow{10}{*}{0.039} \\
\hline Body Mandible & 2 & 14.3 & 5 & 8.3 & 5 & 19.2 & 12 & 12.0 & & \\
\hline Condyle Mandible & 0 & 0.0 & 12 & 20.0 & 2 & 7.7 & 14 & 14.0 & & \\
\hline Parasymphysis Mandible & 1 & 7.1 & 6 & 10.0 & 1 & 3.8 & 8 & 8.0 & & \\
\hline Symphysis Mandible & 0 & 0.0 & 3 & 5.0 & 1 & 3.8 & 4 & 4.0 & & \\
\hline Lefort I Maxilla & 0 & 0.0 & 0 & 0.0 & 1 & 3.8 & 1 & 1.0 & & \\
\hline Lefort II Maxilla & 0 & 0.0 & 2 & 3.3 & 0 & 0.0 & 2 & 2.0 & & \\
\hline Lefort III Maxilla & 0 & 0.0 & 1 & 1.7 & 0 & 0.0 & 1 & 1.0 & & \\
\hline Zygoma & 2 & 14.3 & 7 & 11.7 & 1 & 3.8 & 10 & 10.0 & & \\
\hline Zygomatic Arch & 1 & 7.1 & 13 & 21.7 & 12 & 46.2 & 26 & 26.0 & & \\
\hline
\end{tabular}

Frequencies of different parameters assessed (table -1) shows males at the age group of 21 to 30 years suffered maxillofacial injuries under the influence of alcohol. RTA was the most common etiology and Mandibular fracture is the commonest type of fracture encountered.

On assessment of age distribution (fig-1)it reveals that the most vulnerable age group is 21 to 30 years followed by 31 to $40 \mathrm{yrs}$ and 41 to 50 years with equal frequency. Males (94\%) suffered maxillofacial trauma under the influence of alcohol in a larger proportion compared to females (fig-2). RTA is the most common etiology followed by self fall and then assault (fig-3).

On assessment of type of fracture (fig-4), the most common fracture encountered were fracture Mandible (symphysis,parasymphysis,angle,body,ramus and condyle of the mandible). Mandibular fracture $(60 \%)$ was followed by fracture zygoma (36\%) (zygomatico maxillary complex and the zygomatic arch). In mandibular fracture the common subtype encountered was angle of the mandible followed by mandibular condyle.

On analysis of the association between the parameters such as age and the etiology of trauma under the influence of alcohol (table-2), the most vulnerable age group being 21 to 30 years and they succumbed to RTA was elicited.

Association between the commonest types of fracture in the vulnerable age group of 21 to 30 years (table-3) revealed that this particular age group had fracture Mandible more commonly than fracture Zygoma.

Further, the association between the etiology and the type of fracture (table-4) revealed that most of the RTA resulted in fracture Mandible followed by fracture Zygoma.

\section{Discussion:}

Alcohol drinking is a severe socio economic issue in India. Consumption of alcohol small amounts every day, drinking alcohol $6 \mathrm{hrs}$ before driving, binge drinking everyday or occasionally in a week all leads to RTA ${ }^{6}$. RTA is the major etiology of maxillofacial trauma in developing countries like India ${ }^{7}$. Alcohol abuse and its relationship to trauma had reached massive proportions ${ }^{8}$.

Alcohol with blood levels $0.04 \mathrm{~g} / \mathrm{dl}$ can hinder in patients decision making and does not make them to realise the foreseen danger, $0.05 \mathrm{~g} / \mathrm{dl}$ increases the risk by $1.83 \%$ and affects treatment and prognosis in RTA management ${ }^{9,10,11}$. In India alcohol breath testing is done randomly on susceptible drivers in police checkpoints. Alcohol breathe testing and alcohol blood testing is done on crash drivers in the hospitals but a clear data on this is lacking. Thailand is the only south East Asian country to enforce special blood alcohol concentration limit ${ }^{12}$.

Alcohol interferes with neuro transmission and the function of brain receptors ${ }^{13}$. This decrease in function makes people fearless and less bothered about legal or 
health implications ${ }^{14}$.Alcohol consumption reduces cognitive behaviour and reduces a person's problem solving ability in a conflicting situation. Further it causes increase in aggressiveness and increases emotional responses ${ }^{15-18}$. Adeyoma et $\mathrm{al}^{19}$ recorded that $90 \%$ of fatalities in developing countries were because of RTA under alcohol abuse.

Use of restraints such as helmets and seat belts is of paramount importance in preventing maxillofacial trauma. Bekal et $\mathrm{al}^{20}$ recorded that the incidence of maxillofacial trauma increased due to non utilisation of restraining devices in and around Bengaluru, India. Helmets are not gender specific. In India a common misconception is that full facial helmets are meant for males and semi helmets are meant for females. This renders most of the females vulnerable to facial fractures. Although use of restraints such as helmets and seat belts are mandatory in any part of India, the compliance is less. Bekal et $\mathrm{al}^{20}$ and Pandey et $\mathrm{al}^{21}$ recorded maxillo facial fractures in RTA because of not wearing helmets or not wearing seat belts.

In our study males were commonly affected than females which are in concurrence with most of the studies published from India ${ }^{22,23}$. Puducherry city, capital of the union territory is a former French colony and a major tourist attraction. The city attracts lots of tourists and workers from adjoining rural area. The main modes of transportation are two wheelers and hence the recorded maxillofacial trauma was high in males as males are the earning members in developing country like India. We recorded maxillofacial trauma in six females who were pillion riders without use of helmets or wearing semi helmets under the influence of alcohol.

Mandible is the most common fracture encountered in this region $(60 \%)$. This can be explained by the fact that most of the injuries are due to RTA involving motorised two wheelers without the use of helmets. The next common type of fracture being zygoma and zygomatic arch (36\%). The type of fractures recorded were similar to the study recorded by Kapoor et $\mathrm{a}^{24}$.

\section{Conclusion}

The descriptive study, maxillofacial trauma under alcohol abuse clearly reveals the association of the trauma under the influence of alcohol in and around Puducherry. Use of restraining devices, proper maintenance of faulty roads, rehabilitation of drunk and drive crash drivers to prevent repeated injury are mandatory.

\section{References}

1. Pal R, Ghosh A, Kumar R, Galwankar S, Paul SK, Pal S, Sinha D, Jaiswal A K, Moscote-Salazar LR, Agrawal A. Public health crisis of road traffic accidents in India: Risk factor assessment and recommendations on prevention on the behalf of the Academy of Family Physicians of India. J Family Med Prim Care 2019;8:775-83.

2. Jaiswal AK, Krishna S, Agarwal A, Ghosh A, Pal R. Alcohol and road safety: Investigation and legal aspects. Al Ameen J Med Sci 2018;11:154-60.

3. Pal R, Agarwal A, Galwankar S, Swaroop M, Stawicki SP, Rajaram L, et al. The 2014 Academic College of Emergency Experts in India's INDOUS Joint Working Group (JWG) White Paper on "Developing Trauma Sciences and Injury Care in India.” Int J Crit Illn Inj Sci 2014;4:114-30.

4. Pal R. Injury science in India: Call for the action. Indian J Prev Soc Med 2012;43:229-32

5. HO. Report of the Committee on Road Safety and Traffic Management, The Secretariat for the Committee on Infrastructure Planning Commission, Government of India [online] Available from: www.infrastructure.gov.in.

6. Watt K, Purdie DM, Roche AM, McClure RJ. Risk of injury from acute alcohol consumption and the influence of confounders. Addiction 2004; 99:1262-73

7. Karne M, Mishra S, Ashish T, et al. Study of pattern of injuries by road traffic accident on National Highway-24. International Journal of Contemporary Surgery 2017;5:37-41.

8. Rehm J, Gmel G, Sempos CT, et al. Alcohol-related morbidity and mortality. Alcohol Res Health 2003;27(1):39-51.

9. Gururaj G. Alcohol and road traffic injuries in South Asia: Challenges for prevention. J Coll Physicians Surgeons Pakistan 2004;14:713-8.

10. Gururaj G. The effect of alcohol on incidence, pattern, severity and outcome from traumatic brain injury. J Indian Med Assoc 2004;102:157-60, 163.

11. McLean A, Holubowycz OT. Alcohol and the risk of accident involvement. Alcohol, drugs and traffic safety Proceedings of the 8th International Conference on Alcohol, Drugs and Traffic Safety, Stockholm; 1980:15-9

12 Regional report on status of road safety: WHO 
South-East Asia region. [online] Availabe from: http://www. searo. who.int/entity/disabilities injury_rehabilitation/documents/9789290223559/ en

13. Pihl RO, Peterson JB, Lau MA. A biosocial model of the alcohol aggression relationship. J Stud Alcohol Suppl 1993;11:128-39

14. Pihl RO, Hoaken PN. Biological bases of addiction and aggression in close relationships. In: Wekerle $\mathrm{C}$, Wall AM, editors. The violence and addiction equation: theoretical and clinical issues in substance abuse and relationship violence. New York: Brunner-Routledge; 2001. p. 25-43.

15. Peterson JB, Rothfleisch J, Zelazo P, Pihl RO. Acute intoxication and cognitive functioning. J Stud Alcohol 1990;51:114-22.

16. Sayette MA, Wilson GT, Elias MJ. Alcohol, aggression: a social information processing analysis. J Stud Alcohol 1993;54:399-407.

17. Pliner $\mathrm{P}$, Cappell $\mathrm{H}$. Modification of affective consequences of alcohol: a comparison of social and solitary drinking. J Abnorm Psychol 1974;83:41825.

18. Rhem J, Room R, Graham K, Monteiro M, Gmel $\mathrm{G}$, Sempos CT. The relationship of average volume of alcohol consumption and patterns of drinking to burden of disease: an overview. Addiction 2003;98:1209-28.

19. Adeyemo WL, Ladeinde AL, Ogunlewe MO, et al. Trends and characteristics of oral and maxillofacial injuries in Nigeria: a review of the literature. Head Face Med 2005;1:7

20. Bekal M, Brijesh K, Suresha KR. Retrospective analysis of the effect of alcohol abuse and restraining device on maxillofacial injury- a study of 225 cases. J. Evolution Med. Dent. Sci. 2019;8(47):3526-30

21. Pandey S, Roychoudhury A, Bhutia O, et al. Study of the pattern of maxillofacial fractures seen at a tertiary care hospital in North India. J Maxillofac Oral Surg 2015;14(1):32-9

22. Shankar AN, Shankar VN, Hegde N, et al. The pattern of the maxillofacial fractures-a multicenter retrospective study. J Craniomaxillofac Surg 2012; 40(8):675-9

23. Gupta R, Suryanarayan S, Sharma A, et al. Traumatic mandibular fractures: pendulum towards closed reduction. The World Articles in Ear, Nose and Throat 2010;3:1-3

24. Kapoor P, Kalra N. A retrospective analysis of maxillofacial injuries in patients reporting at a tertiary care hospital in East Delhi. Int J Crit Iln Inj Sci 2012;2(1):6-10 